\title{
East German economic elites and their companies two decades after the transformation ("Wende"): Still following the patterns of the 1990s*
}

\author{
Bernd Martens**
}

Surveys among entrepreneurs and managing directors of companies with 50 to 1,000 employees are used to describe features of managerial elites in East Germany. The paper looks at four dimensions: (1) the reproduction of economic elites during the transformation period and its current consequences; (2) the development of "family capitalism" and processes of social closure; (3) qualification patterns of management; and (4) different attitudes of East and West German elites. Managers who were socialised in state socialist combines are still a large proportion of East German economic elites. Owing to their age distribution, changes in top management will be probable, and their effects on enterprises and social relations are discussed in the paper.

Befragungsdaten von Leitern eigenständiger Industrieunternehmen der Größenklassen 50 bis 1,000 Beschäftigte werden genutzt, um gegenwärtige Entwicklungen ostdeutscher Wirtschaftseliten zu beschreiben. Es werden vier Analysedimensionen berücksichtigt: (1) die Reproduktion ökonomischer Eliten nach der Wende und ihre Auswirkung auf die Unternehmensführungen heute; (2) die Entwicklung „familienkapitalistischer" Strukturen in Ostdeutschland und Prozesse der sozialen Schließung; (3) Qualifikationsprofile des Managements sowie (4) Einstellungsunterschiede zwischen ost- und westdeutschen Wirtschaftseliten. Die ostdeutschen Unternehmungsleitungen umfassen immer noch viele Personen, die in der DDR-Wirtschaft sozialisiert wurden. Aufgrund der Altersstruktur dieser ostdeutschen Eliten ist ein künftiger Generationswechsel an der Spitze von Unternehmen wahrscheinlich, dessen mögliche Folgen für Unternehmen und betriebliche Sozialordnungen diskutiert werden.

Keywords: Survey, managerial elites, East Germany, different attitudes, Managers, distribution, changes

* Manuscript received: 18.02.08, accepted: 03.09 .08 (1 revision)

** Bernd Martens, Senior Researcher, Collaborative Research Centre 580, University of Jena. Main research areas: Sociology of management and transformation process of Rast German companies. Corresponding address: bernd.martens@uni-jena.de. 


\section{Introduction}

The economic transformation in East Germany is only partly understood. As previous studies have revealed, it was not accompanied by a replacement but by a reproduction of economic elites (Gergs et al. 1997; Schreiber et al. 2002). The process did not lead to manager capitalism (Windolf 2001), or to a colonisation of East German management by West Germans, as most of the managers in East German firms were from an autochthonous background (Windolf et al. 1999:65).

About a third of companies in the industrial sector are still owned or controlled by West Germans or foreigners. However, even two decades after system transformation, information about them or the remaining two thirds of managing directors and entrepreneurs with an East German social background is limited. This holds true for the degree of continuity or change in regard to the careers of economic elites, and for the development of ownership structures and qualification profiles as important features in describing the peculiarities of management cultures. It is also true of the attitudes of economic elites concerning society, the state, and politics, as important cognitive dimensions of social change. This paper sheds light on these topics by using data on senior management of manufacturing industry firms in Germany. The focus is on East Germany; the West German cases are mainly used for comparative purposes.

The study does not refer to top-level management of huge corporations or representatives of economic associations, since East German managers and businessmen are not members of these circles. Nevertheless, our respondents can be labelled elites, according to the following definition: "We conceive of an elite as a social circle of individuals that, in a socially relevant area (a large social context or a 'sub-system') and a defined social space, are recognised as entitled to rule or to lead [...]. At the same time the members of these social circles have privileged access to socially relevant resources and/or the option of exerting influence over their distribution" (Gergs et al. 1997:207). Our respondents possess features of economic elites on a local or regional level; they are important social actors in towns and counties. The results with regard to company ownership, careers, qualifications, social origin, and attitudes can be summarised by three theses about past, present, and future of this group of actors.

East German top management is to an astonishing extent influenced by the past, thanks to the reproduction of economic elites who had already held responsible positions before 1989 and who used a rather short window of opportunity to reach the first organisational level of companies at the early 1990s. At present, a striking "orthodoxy of proselytes"1 characterises the majority of East German

1 A proselyte is in the Old Testament a "stranger", a newcomer to Israel, a sojourner in the land. In the New Testament the term denotes a convert to Judaism. 
entrepreneurs and executives, in comparison to their western counterparts. Neoliberal attitudes, combined with a fatalistic approach to the nature of capitalist competition, are widespread among East German managers. It is uncertain how long such attitudes will remain in place. However, given the age structure of East German management, a generation change at the top-level of companies and the formation of family capitalism is probable in the future. Both will presumably change employment relations in the firms where there are at present the first indications that the consensus reached between management and workforce during the transformation period ("Nachwendepakt") will become weaker.

\section{The empirical basis}

In 2002, computer assisted telephone interviews were carried out with executives and entrepreneurs. ${ }^{2}$ The sample included independent enterprises of the German manufacturing industry with 50 to 1,000 employees. The standardised questionnaire comprised questions about the characteristics of the companies and responsible persons of the first organisational level (entrepreneurs, managing directors, executives, or CEOs). The response rate was $26.4 \%$ (Martens/Michailow 2003). The survey was replicated in 2005 following a panel design. Two samples are thus available with nearly 800 cases in each survey. 34.0 and $38.0 \%$ of the samples relate to East Germans. ${ }^{3} 538$ companies took part in both surveys. The resulting panel data set allows analyses of changes over time at the level of the company. Event history data (Yamaguchi 1991:1-9), which precisely map career dynamics of the respondents, were also collected in 2002, and in addition, guided or in-depth interviews with executives and entrepreneurs were held during 2002 to 2007. The topics covered in these interviews were the same as those in the standardised questionnaires, but it was possible to discuss them in much more detail. In co-operation with British research partners, in 2005, we also replicated the standardised survey using comparable English enterprises.

2 The data were collected in the research project "Stability or change of management strategies in East and West Germany" (Martens et al. 2003). This research is part of the Collaborative Research Centre 580 "Social developments after structural change" at the universities of Jena and Halle (http://www.sfb580.uni-jena.de).

The regional background of the respondents was measured in our surveys by the question, where did the respondent live in June $30^{\text {th }}$, 1990? The categories were: in the German Democratic Republic or elsewhere, respectively. Related to our whole sample of executives and entrepreneurs, $42.6 \%$ are West Germans (WG) working in the West, $19.4 \%$ are WG in the East, $37.0 \%$ are East Germans (EG) who were engaged in the East. Only seven EG worked in the West (survey 2005, number of cases: 702). 


\section{Results on East German managerial elites}

\section{The social background of the study}

The developments that took place after unification drastically altered the economic structures in East Germany. The big industrial complexes (state combines) were broken up and a large number of firms were dissolved. The consequence was a temporary reduction in production by one third in 1990/91 and a permanent de-industrialisation (Kollmorgen 2005:202-245; Windolf 2001:396). In 2004, in the East German manufacturing industry, companies with 50-249 employees employed $35.8 \%$ of the workforce (Institut für Mittelstandsforschung 2007). The comparable figure in the west was $26.1 \%$, whereas over one half of the western working force (51.6\%) was employed in firms with more than 250 employees. The turnovers of this last type of company accounted for $60.3 \%$ of all turnovers in the industrial sector in West Germany. In East Germany, the corresponding percentage was only $32.0 \%$.

Small and medium-sized companies are often so-called family businesses which have a long tradition not only in Germany. Features of these companies are that ownership and entrepreneurship coincide and continuity of the company is traditionally realised within the family of the entrepreneur-owner (Colli 2003). The destinies of such enterprises "are closely associated with that of the entrepreneur and that of his [or her] family" (Kotthoff 1993:234-235). The high proportion of rather small firms in East Germany and the strong influence of entrepreneurs or executives on these organisations determined the design of our investigations.

\section{The "long shadow of unification"4}

A special situation occurred in East Germany with regard to the economic transformation, because there was a rapid change of institutions while the economic elites were reproduced to a significant extent (Martens 2007a). Whereas an abrupt structural break happened, the change of generations was partly disrupted, because the new entrepreneurs were essentially recruited from GDR management. The founders of "successor" firms, that had been before 1990 part of GDR combines, had frequently worked as economic cadres (leading employees) (Hatschikjan 1998:258) describes the transformation process and the recruiting of new business elites during the early 1990s as "revolution of the deputy department chiefs".

Kotthoff and Matthäi (1999:100), in their study of economic transformation in East Germany, point to special types of entrepreneurs who had a social background in the GDR. They found among others "senior entrepreneurs" who

4 Martens (2005). 
took their opportunities to control a company at an unusually advanced age, as well as "entrepreneurs against their own will" who were forced by circumstances to follow a new profession, in order to avoid unemployment (Matthäi 1996:153-171).

Both types of these entrepreneurs appear in the empirical material of the Jena management study, but with a preponderance of the former type. A group of East German entrepreneurs and executives which is still dominant has a professional background in the socialist economy of the GDR (Martens 2005). The percentage of East German persons who reached leading positions before 1989 and still in such positions is $77 \%$. The corresponding figure for the West German sample is $59 \%$ (survey data 2005).

Figure 1. Age distribution of respondents, number of cases: 297 (East), 431 (West), survey 2005

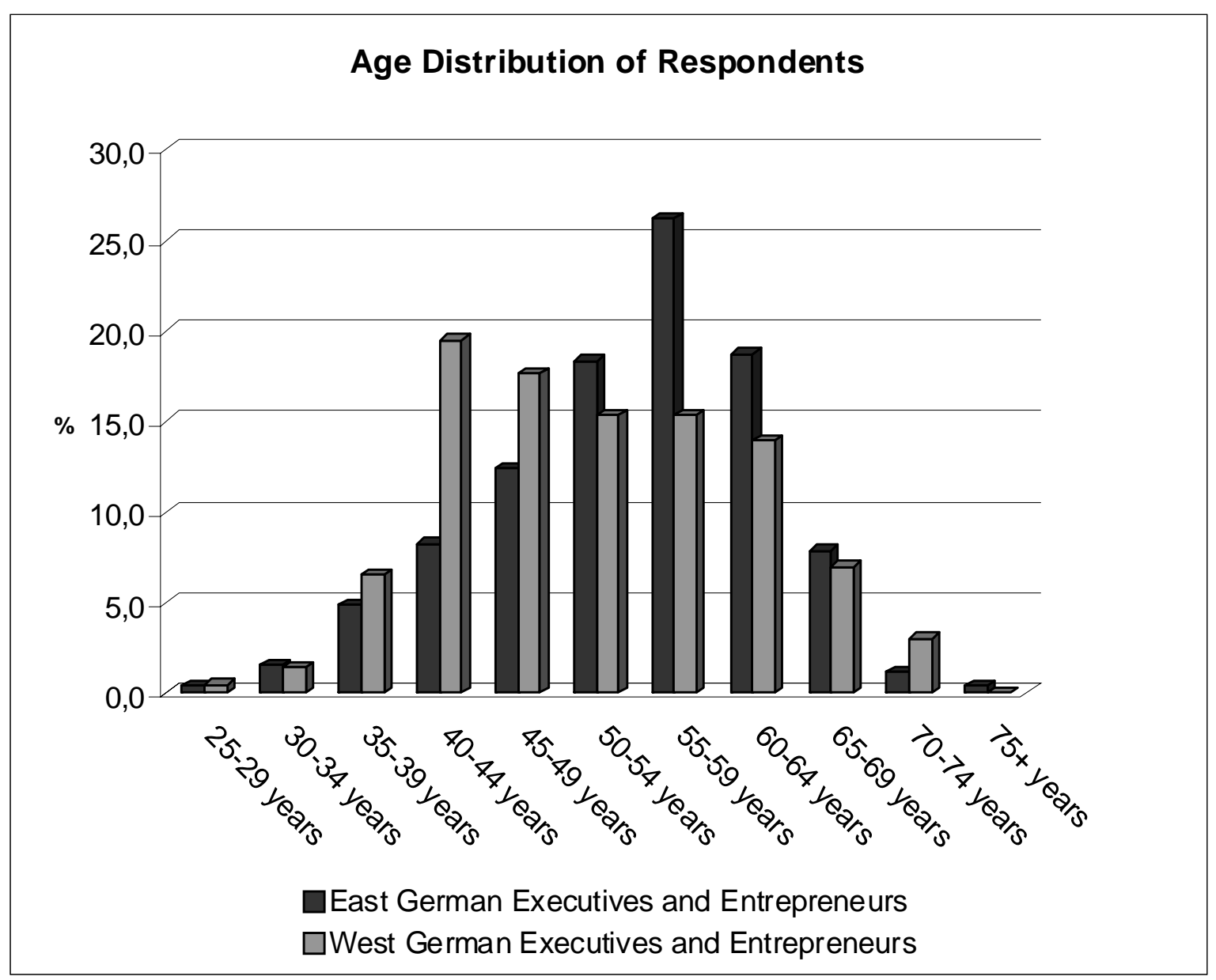

The age distributions of our respondents also illustrate the high proportion of "senior entrepreneurs" in East German management. At first glance, the difference between the mean ages of respondents seems to be rather small: 52.2 years (East) and 49.8 years (West). But the difference is statistically significant 
(t-test, $\mathrm{p}<0.001$ ), and the whole distributions are furthermore quite different (Kolmogorov-Smirnov test, $\mathrm{p}<0.00$, Figure 1). Older age groups occur more often in East German top management. The ages of the largest cohort in the 2005 survey was between 40 and 45 years at the beginning of the 1990s. In contrast to the age structure of the East German sub-sample, that of the West German respondents is more "balanced". Persons who are younger than 45 years appear with greater frequency. Due to the special age structure of managerial elites, a change in East German top-level management is probable within the coming years. The consequences of this process are discussed in the following sections.

Figure 2. Length of time spent at the most recent position, event history data of careers, number of cases: 253 (East), 483 (West), survey 2002

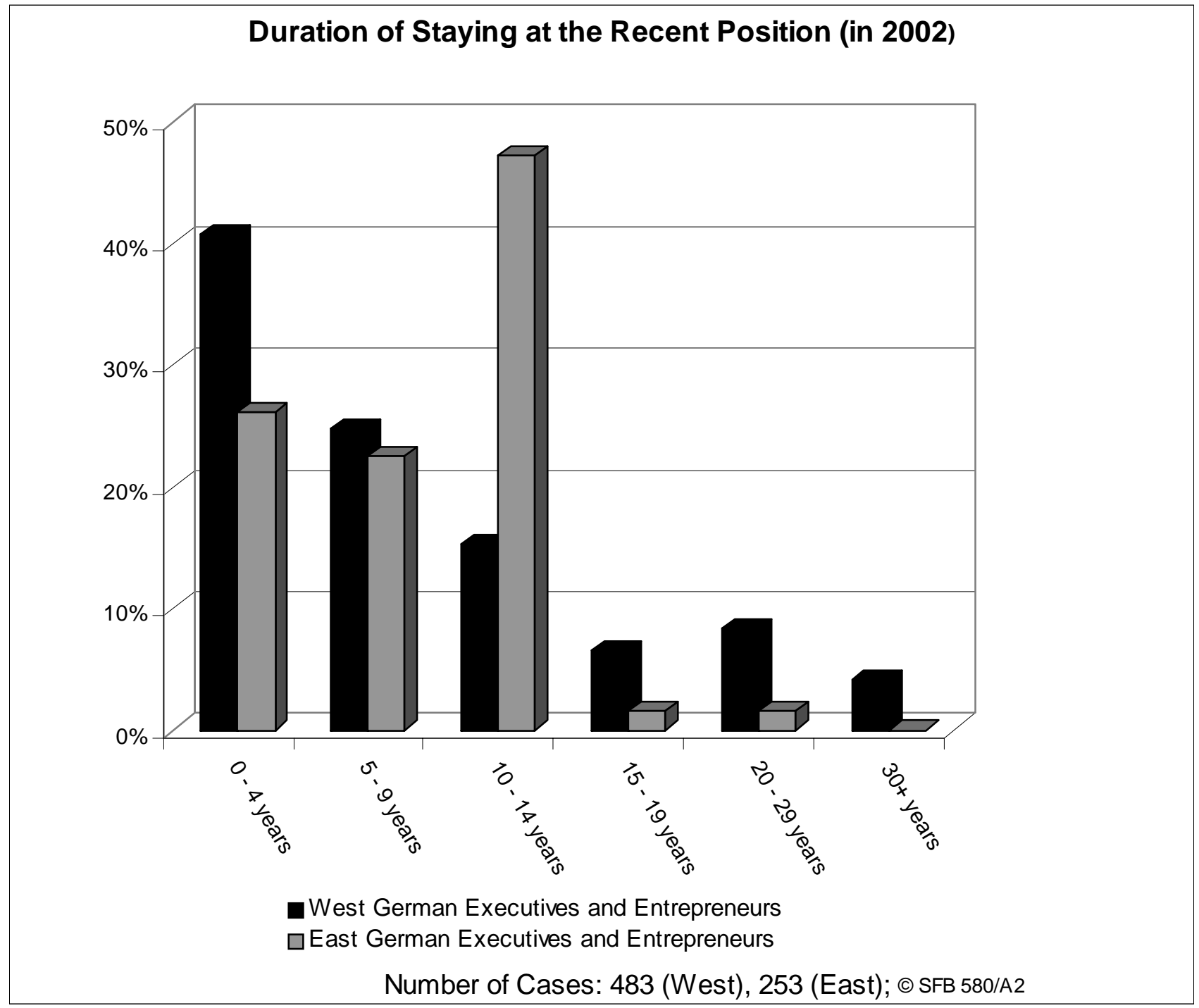

A second impression on career patterns is provided by a comparison of the retention period in the position that the respondents occupied at the year of the survey (the following analyses refer to the event history data on careers 2002). 
The distributions of the East and West German respondents differ widely (Figure 2): a majority of East German executives and entrepreneurs apparently used short windows of opportunities to obtain their positions. These windows of opportunities existed at the beginning of the 1990s and these persons have since remained rather immobile in their positions. The length of time spent at the position also correlates positively with ownership of company shares.

A multivariate method (optimal matching of sequence data ${ }^{5}$ describing careers of East German respondents during the time frame 1981-2001) reveals that some of the economic elite's current characteristics - such as age structure, job mobility, company ownership, and qualifications - are still influenced by the windows of opportunities that existed in the early 1990s. It is possible to reduce the careers of East German managerial elites to three patterns of sequences of occupational states (jobs):

(1) The dominant career pattern can be circumscribed by the term "continuousness". Persons belonging to this type are essentially senior entrepreneurs and did not change company, only their position. Executives and entrepreneurs of this career type had always been - before and after unification in the same economic organisation. This holds true for $53.6 \%$ of the East German sample and it describes the main structure of opportunities which are relevant for East German business elites in the beginning of the 1990s: seeking their chances in the firm they know. These careers are examples of so called "in house careers" regarded as traditionally German (Faust et al. 2000; Bauer/Bertin-Mourot 1999:19; Hartmann 1996). ${ }^{6}$

(2) A second group of persons, encompassing $27.0 \%$ of the East German sample, reached the top-level of companies only by changing firm or by founding a new one, also at the beginning of the 1990s. This group exhibits a different type of mobility and flexibility and it can be denoted as the founders.

(3) The last cluster includes respondents who are younger and who do not possess company shares. Their careers often show them rising to top-level positions at the end of the 1990s. They seem to represent a new generation of managers (Martens 2005:225).

5 The careers are regarded as sequences of states during a given time frame. All sequences are compared according to a special distance measure and classified by cluster analysis (Abbott/Tsay 2000). In our case, states are hierarchical positions and whether a person changes firm to get a new job. Optimal matching of career sequences leads to seven clusters for the East German respondents (Martens 2005:218-225).

6 In general, careers within one company seem to be a feature of large corporations. The 2002 and 2005 samples indicate that this career type is not very common among top managers of German firms. $23 \%$ of the employed managing directors have had careers without changing company. Only those who inherit company shares (second generation or more) reveal higher degrees of stability $(56 \%)$. 
Further analysis reveals that the career type depends on ownership of companies. This holds true especially for the first and second career pattern. The use of the windows of opportunities frequently implied the necessity of buying company shares. A majority of East German executives and entrepreneurs are consequently owners of their companies.

\section{The emergence of family capitalism}

An analysis of the economic ownership structure of firms is generally very difficult, because the distributions of minority and majority shares can be rather complicated and they can change very rapidly. In addition, entrepreneurs, owners, and managers are often not very communicative about the structures of ownership in "their" companies. Therefore, it is not easy to gather information about this, especially by means of standardised questionnaires. Kollmorgen (2005:203/211) cites for example two different studies which give in the first instance disagreeing approximations of ownership in East German economy. The first one estimates that East Germans own 20-25\% of all productive properties (in relation to the entire East German economy, Windolf 2001: 402 publishes a similar figure for the year 1995). The second one claims that $85 \%$ of the companies in the manufacturing industry are in the possession of East German entrepreneurs. Both studies are presumably right, because of different empirical bases, but the different figures illustrate the general difficulty of giving a valid picture of the situation.

It was also very difficult in our survey to collect data about these crucial but rather sensitive issues. However, on the basis of these data, it is possible to reject some conjectures of the 1990s. It was assumed that the privatisation of the East German economy would support a "manager capitalism" with high frequencies of employed managers without company shares. The current proportion of owners is larger among the East German respondents than among their western counterparts (55\% and $44 \%$, respectively, survey 2005). The percentage of majority owners is however smaller owing to lack of capital. $30.3 \%$ of the East Germans, possessing company shares, are majority owners. The percentage among the West German respondents is higher (40.5\%). Additionally, the companies of the latter are larger. The mean size of these companies amounts to 174 employees, and the average turnover is 38.3 million $€$. The analogous figures for the East Germans are 107 employees and 16.5 millions $€$. The corresponding medians of turnovers and number of employees illustrate the

7 The group of West German managing directors working in the East reveals some characteristics which have similarities to a manager capitalism: the proportion of ownership is lower $(35.6 \%)$ and they frequently have experience of work in foreign countries (33.1\% compared with $13.4 \%$ of the "remaining" West Germans). 
$\mathrm{SME}^{8}$ bias of East German economy. Turnovers: 8 millions $€$ (East German firms), 16 millions $€$ (West German firms); company's size: 80 employees (EG), 105 (WG). These figures also point out that East German firms exhibit an inferior turnover/company size ratio.

Ownership of firms, even if it only includes minority shares, is one part of an emerging "family capitalism" in East Germany. Plans and wishes expressed by the respondents about the future of enterprises confirm this statement. We asked in the questionnaires for the planned transfer of businesses and found no differences between the East and the West German samples. Equal majorities of respondents in both data sets wish that the transfer of business should take place traditionally within the family: $43 \%$ of the persons in both East Germany and West Germany, who plan a transfer of business in the near future, would do it within kinship. All other solutions of managing the transfer are of minor relevance. These findings, which illustrate some features of family capitalism, correspond to those of other studies (Günther/Gonschorek 2006:17). In connection with the expected generation change in East German top management, it is plausible that a type of family capitalism will emerge in East Germany despite large proportions of minority shares (Martens 2007a), because there is very little overlapping between private and corporate/institutional stockholders; if, for example, a person or a family own a firm, other types of stockholders are rarely involved as well. ${ }^{9}$

During recent years, a discussion has taken place in German sociology on the occupational achievement of elites and their social origins. Studies on German top management show that the reproduction of economic elites essentially depends on social background (Hartmann 2002). According to these investigations, the reproduction of economic elites in Germany reveals a remarkable extent of social closure, which is defined as actions of social groups who restrict entry and exclude benefit to those outside the group in order to maximise their own advantage (Bilton et al. 1996:669). Our findings on executives and entrepreneurs point in the same direction: the occupations of their fathers influence the occupational achievement of young West German business elites. In addition, processes of social closure are of growing importance for the East German sub-sample as well. Kulke (2005:258) reports on similar findings on another empirical basis: the East Germany managerial

8 According to the definition of the European Union small and medium-sized enterprises (SMEs) have between 10-249 employees.

9 This statement refers to a comparable data set about 312 firms where ownership structures are examined in much more detail, in 2007. Overlap between different types of stockholders occurs only in $11 \%$ of all cases with minority shares. Results of the study were firstly presented by K. Bluhm and B. Martens at the EGOS Conference, Amsterdam in July 2008. 
elite "consists of technical educated academics from a privileged social background".

At first, the average time taken to reach the first top-level position does not give clear indication for this result: West German respondents achieve such position by a mean age of 37.9 years, in contrast to East Germans who need 39.5 years (the figures refer to event history data on careers which was collected in 2002). In general, the average "speed" of achievement is slightly greater for the West Germans. However the comparison of these means does not show significant differences regarding the occupational position of the respondents' fathers.

Figure 3. Occupation of the father according to age cohorts, West German sample, survey 2005

\section{Occupation of the Father, West German Respondents}

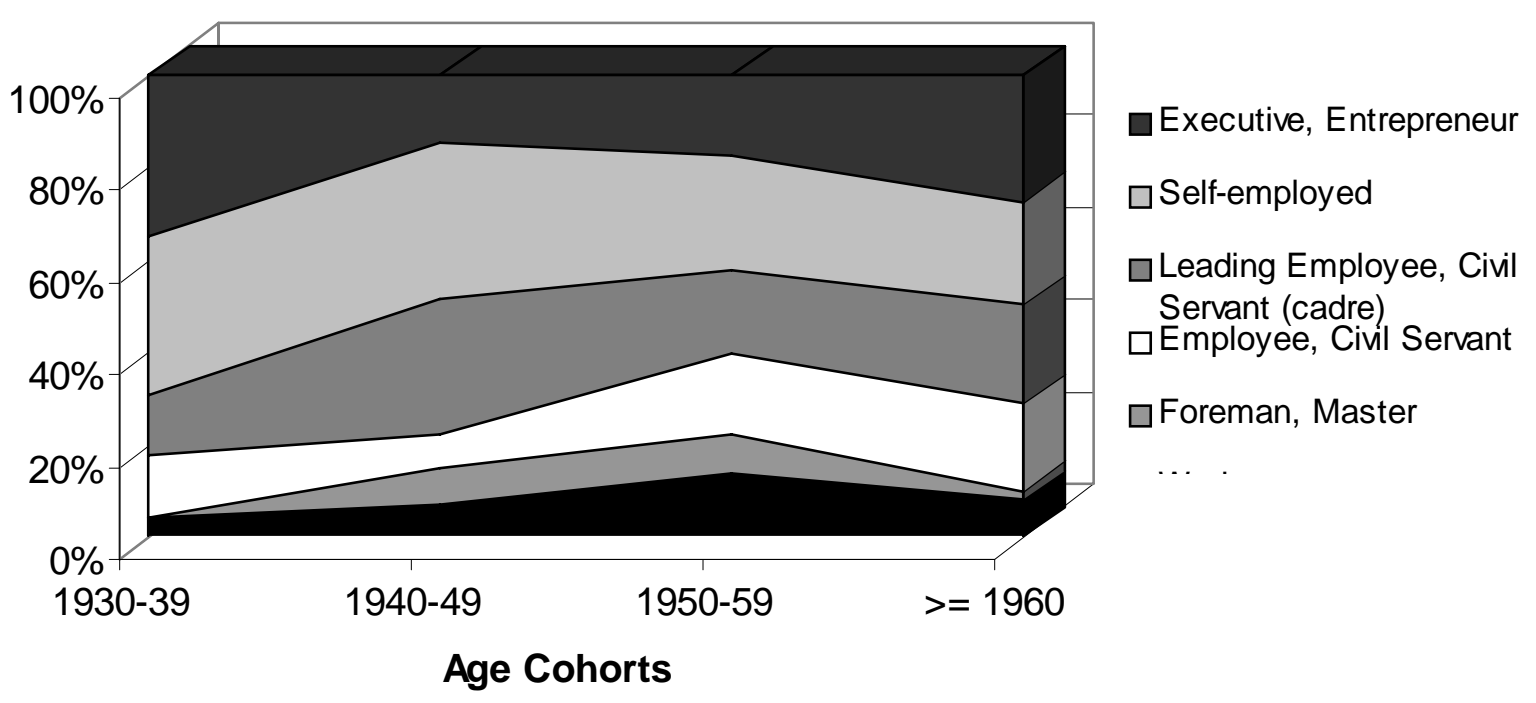

Nevertheless, an analysis of these occupational positions of the fathers according to age cohorts shows that the relative frequencies of children of executives, entrepreneurs, and self-employed are stable (Figure 3). The distribution of the East German respondents is, of course, quite different - in older age cohorts the percentages of children from a lower social background (children of workers, foremen, masters) are higher -, but it reveals the interesting fact that younger cohorts increasingly have fathers who had been in leading positions during the socialist era (Figure 4). These results correspond with findings of studies using totally different empirical sources (Best 2007; Best/Remy 2006; Salheiser 2006:89; Kulke 2005). 
Figure 4. Occupation of the father according to age cohorts, East German sample, survey 2005

\section{Occupation of the Father, East German Respondents}

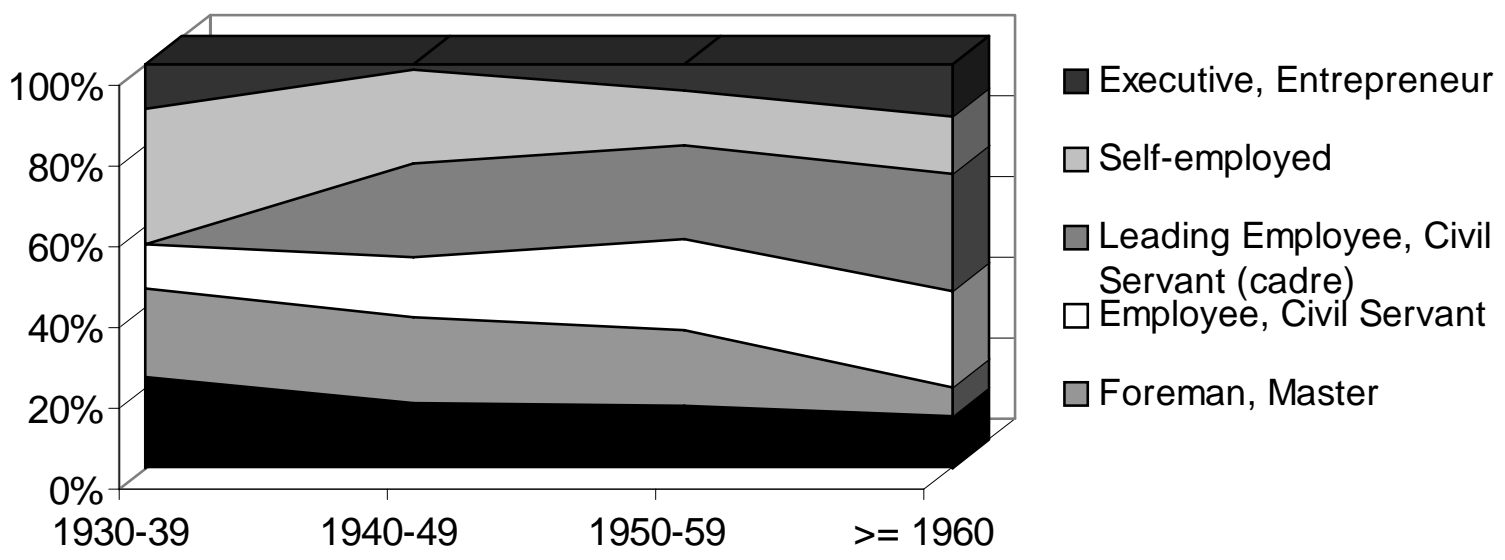

Age Cohorts

In general, the number of women in top-level management is small. Relatively more East German women occupy the highest positions of small and mediumsized companies $\left(10.1 \%{ }^{10}\right.$ compared with $5.3 \%$ of the West German sample, survey 2005), but further analyses show that the most successful way to increase the likelihood of getting a top-level position is by being related to the entrepreneur. The proportion of women in the group of company inheritors amounts to $16.5 \%$; the corresponding percentages in other categories of management (entrepreneurs of the first generation and employed executive without shares) range between 5.2\% and 6.5\% (Martens/Michailow 2006:230).

The analysis of the simple bivariate frequency distributions has some shortcomings: the careers have different durations. Hence the probability of reaching a certain position varies with age. In order to correct this, the career data are standardised by taking into account the first 45 years of life and the following question is considered: which independent variables exert influence on reaching a top-level position in management during the time frame of the first 45 years of life?

10 The percentages of male managers increased with the hierarchical level in the GDR's industry: $70 \%$ (team leader), $82 \%$ (manager of department), $90 \%$ (head of department), $96 \%$ (managing director, Salheiser 2006: 90). 
The effects of several independent variables were estimated by logistic regressions (Long 1997), separately for the West and East German sample of "standardised" career data. The dependent variable is the probability of reaching a top-level position by the age of 45 . This variable possesses only two values: executives/entrepreneurs on the one hand and all other positions on the other hand. Thus the dependent variable indicates whether a person reaches a position at the first organisational level of a company during the time frame in question.

The following independent variables were taken into account: age ${ }^{11}$, technical and economic qualifications, social origin measured by the occupational position of the father, change of company during the time frame (long careers in one firm are measured in this way).

Unfortunately, ownership of company shares could not be taken into consideration, because such information was only available for the enterprise where the respondent worked in 2002. The analyses assess the probability of getting a position at the top-level of a company depending on variations of the independent variables. Only a few of them have significant impacts (Table 1).

Table 1. Results of a logistic regression for reaching a position as executive by the age of 45 years, survey 2002, event history data, odds ratios, values $<1$ indicate a negative influence, values $>1$ a positive one

\begin{tabular}{|l|c|c|}
\hline Independent variables & West German sample & East German sample \\
\hline $\begin{array}{l}\text { Cohorts (the cohort 1950-59 } \\
\text { is the reference) }\end{array}$ & & \\
\hline $1930-49$ & $0.453^{*}$ & $0.231^{* *}$ \\
\hline $\begin{array}{l}\text { Social background, } \\
\text { occupation of the father } \\
\text { (executive, entrepreneurs is } \\
\text { the reference) }\end{array}$ & & \\
\hline Worker or employee & & \\
\hline Leading position & 0.529 & 0.550 \\
\hline Qualifications & $0.442^{*}$ & 0.840 \\
\hline Technical & & $3.206^{*}$ \\
\hline Economic & 0.663 & 2.434 \\
\hline Change of company & 1.329 & 1.031 \\
\hline N & 0.803 & 180 \\
\hline Nagelkerke's Pseudo $\mathrm{R}^{2}$ & 293 & 0.177 \\
\hline
\end{tabular}

Notes: ${ }^{*} \mathrm{p}<.05,{ }^{* *} \mathrm{p}<.01$.

The results for the West German sample can be summarised as follows:

11 Owing to the small numbers of cases, the cohorts 1930-39 and 1940-49 are combined. For the same reason, the gender variable cannot be introduced into the logistic regressions. 
$>$ There is a strong influence of social background. Children of workers, but also of leading employees (cadres), clearly show smaller probabilities of reaching a position at the top-level of companies, compared with persons who are children of an executive, entrepreneur, or self-employed person.

$>$ The age cohort between 1950 and 1959 reached top-level positions with greater probability than the older cohort.

The variables above explain $9.8 \%$ of variation (Nagelkerke's Pseudo $\mathrm{R}^{2}$ ), whereas in the case of the East German sample, the independent variables describe $17.7 \%$ of dispersion. This relatively large value indicates that the patterns of East German careers are more uniform in comparison to the western counterpart. The result reflects the lack of career chances during the socialist era. Older cohorts have a lesser chance of getting a position at the highest level of enterprises during the first 45 years of their life than the younger cohort. Only $43.8 \%$ of the older cohort 1930-49 reached such positions during the given time frame (the corresponding percentage for the West Germans amounts to $71.4 \%$ ). This illustrates on the one hand the limited chances of positional achievement during the last period of the GDR (Best 2007:29). On the other hand these persons could use the windows of opportunity at the beginning of the 1990s that were mentioned earlier.

The high influence of qualifications (significant coefficients in Table 1 for the East Germans) relates to the importance of academic education in GDR management which will be described in greater detail in the next section.

\section{The dominance of engineers}

One feature of modern economic elites is the preponderance of high qualifications and higher education. Our samples illustrate this for top management in manufacturing industry. $94.4 \%$ of the East German respondents have academic degrees (the percentage for the West Germans is $81.1 \%$ ). These figures reflect the practice of the combines of sending managers to further education. In the course of time the relevance of vocational education for economic elites in Germany is declining. The percentage of persons who have degrees in vocational as well as academic education is decreasing, in general.

Profiles of management's qualifications are recognised as a crucial indicator when characterising national management cultures. The dominance of engineers was traditionally regarded as a special feature of German management (Lane 1995). This held true until the 1980s. Since then the proportion of engineers by comparison with managers with non-technical qualifications has continuously declined in the Federal Republic of Germany, and managers with an economic education have become more important (Eberwein/Tholen 1990). In our West German sample of 2005, the percentage of technically educated managers amounts to $49.8 \%$ (the 2002 survey still revealed $57.8 \%$ ). The percentage of 
personnel of the first hierarchical level with this qualification is currently $47.6 \%$ (survey 2005, Table 2).

Table 2. Distribution of technical and economic qualifications, survey 2005

\begin{tabular}{|l|c|c|}
\hline Qualifications & West German sample & East German sample \\
\hline All cases & $\mathrm{n}=435$ & $\mathrm{n}=220$ \\
\hline Technical (engineers) & $47.6 \% \%^{* *}$ & $82.4 \% \%^{* *}$ \\
\hline Economic & $59.5 \% \%^{*}$ & $26.2 \% \%^{* *}$ \\
\hline Only the cohort $\geq 1960$ & $\mathrm{n}=164$ & $\mathrm{n}=57$ \\
\hline Technical (engineers) & $53.7 \%^{\circ}$ & $68.4 \%{ }^{\circ}$ \\
\hline Economic & $56.1 \% *$ & $38.4 \% *$ \\
\hline
\end{tabular}

Notes: $\mathrm{p}<.10,{ }^{*} \mathrm{p}<.05,{ }^{* *} \mathrm{p}<.01\left(\mathrm{Chi}^{2}\right.$ test $)$

The figures for East German management are quite different, due to the history of the GDR and the transformation. The management of companies in the GDR was traditionally dominated by engineers. Furthermore, high qualifications at an academic level were considered to be a sign of professionalism in management (Salheiser 2006:96). Educational achievements were customarily a necessary, but not a sufficient condition for careers in industrial branches.

Interesting facts about the structure and the reproduction of elites in the GDR have become available during recent years. These studies rely on the Zentraler Kaderdatenspeicher (ZKDS) ${ }^{12}$, which was collected by almost all organisations of the GDR from the 1970s until 1989. The extensive data collection among personnel of various hierarchical levels was meant to optimise the recruitment of cadres. The resulting database, which is now open for social science research, allows extensive analyses of the structure and the reproduction of elites in the GDR.

According to the ZKDS, the strong technical orientation of management was even reinforced by transformation processes in the $1990 \mathrm{~s}$. $78 \%$ of the "Fachdirektoren" (heads of departments) of selected economic branches in the GDR (corresponding to the manufacturing industry of today) were engineers and natural-sciences graduates, while $40 \%$ had economic qualifications. (The percentages exceed $100 \%$, because of multiple qualifications.) This leads to an index of $1.95(78 \% / 40 \%)$. For our sample of East German entrepreneurs and executives (survey 2005) the relation is $82.4 \%: 26.2 \%$, the index is therefore equal to 3.15 . The preponderance of technical skills was hence reinforced during the transformation period. Engineers could exploit career possibilities to a remarkable extent, because their competences were transferable. Pohlmann and

12 The Zentraler Kaderdatenspeicher (Central Cadres Database) was electronically constructed after 1983 under the auspices of the GDR's Council of Ministers (Best/Remy 2006). It nowadays holds information of nearly 669,000 "cadres" (Best/Remy 2006: 13). 
Gergs (1997:551) write: Technicians and engineers "were considered as less burdened ideologically by the 'old' system and they could hence convert their human capital which they accumulated during the socialist past." And Best (2007:43) summarises research on economic elites based on the Zentraler Kaderdatenspeicher: "The selective mechanisms working (during the transformation period) favoured male GDR cadres with formal technical and scientific qualifications who were born after 1940. The majority of survivors of the GDR cadre system were recruited from the age cohorts who had been fully subjected to the combined processes of professionalisation and social closure." Both phenomena were already part of the GDR society.

The technical orientation is dominant in our eastern sub-sample, and the figures for the youngest age cohort reveal that the difference in regard to the West Germans is decreasing, but still exists (Table 2). The long-lasting tradition of technical orientation in the GDR as well as in East Germany additionally seems to be the technocratic basis of managerial authority which is observable for example in some current attitudes concerning the relationship to staff (Martens/Michailow 2003:29-35; Schreiber et al. 2002:202). For example the statement, "The most important criterion for employees acceptance of a supervisor should be his [or her] superior expert knowledge", was assessed by East and West German respondents differently. 62.9\% of the East Germans agreed while the corresponding percentage of the West German is only $48.7 \%$. Differences between types of qualifications will become smaller in the future, since economic degrees and skills have in general a growing importance, but it will still characterise the East German management for a longer period.

\section{The "orthodoxy of proselytes"13}

The difference between attitudes regarding leadership styles is only one case of cognitive varieties between East and West German management. Another, even more prominent example concerns socio-political issues (Table 3). These opinions can be grouped into three sets if one looks at economic competition: general attitudes towards it; options in actions in view of it; and possible consequences of it.

(1) In general, the overwhelming majority of executives and entrepreneurs regard business competition highly. This holds true even if the statements exhibit some closeness to Social Darwinism, for instance: "Market competition is an essential instrument to ensure that the best and most capable people prevail" (Table 3, item 4).

13 Martens (2007b). The term was originally proposed by Rudi Schmidt. 
Table 3. Means of socio-political orientations according to the East and West German respondents and to the two clusters, respectively; survey 2002 (Martens 2007b)

\begin{tabular}{|l|c|c|c|c|}
\hline Items & $\begin{array}{c}\text { Mean } \\
\text { West } \\
\text { G. } \\
\text { sample }\end{array}$ & $\begin{array}{c}\text { Mean } \\
\text { East G. } \\
\text { sample }\end{array}$ & $\begin{array}{c}\text { Mean } \\
\text { “social } \\
\text { market eco- } \\
\text { nomist” }\end{array}$ & $\begin{array}{c}\text { Mean } \\
\text { “competitiv } \\
\text { e capi- } \\
\text { talist” }\end{array}$ \\
\hline $\begin{array}{l}\text { The welfare system of the state obstructs the } \\
\text { international competitiveness of German } \\
\text { enterprises. }\end{array}$ & 1,99 & 2,11 & $2,13^{* *}$ & $1,88^{* *}$ \\
\hline $\begin{array}{l}\text { The state should regulate and control the } \\
\text { economic processes. }\end{array}$ & $4,67^{* *}$ & $4,44^{* *}$ & $4,72^{* *}$ & $4,45^{* *}$ \\
\hline $\begin{array}{l}\text { Free enterprise and social justice are } \\
\text { mutually exclusive. }\end{array}$ & $4,16^{* *}$ & $3,62^{* *}$ & $4,50^{* *}$ & $3,32^{* *}$ \\
\hline $\begin{array}{l}\text { Market competition is an essential instrument } \\
\text { to ensure that the best and most capable } \\
\text { people prevail. }\end{array}$ & 1,76 & 1,77 & $1,82^{*}$ & $1,70^{*}$ \\
\hline $\begin{array}{l}\text { To guarantee that German companies remain } \\
\text { competitive, the participation of employees } \\
\text { should be excluded. }\end{array}$ & $3,56^{*}$ & $3,46^{*}$ & $4,06^{* *}$ & $2,88^{* *}$ \\
\hline $\begin{array}{l}\text { Nowadays competitiveness undermines } \\
\text { social cohesion. }\end{array}$ & $3,11^{* *}$ & $2,65^{* *}$ & $3,46^{* *}$ & $2,37^{* *}$ \\
\hline $\begin{array}{l}\text { The goal of an enterprise must always be to } \\
\text { make the highest possible profit. }\end{array}$ & $2,40^{* *}$ & $2,00^{* *}$ & $2,63^{* *}$ & $1,83^{* *}$ \\
\hline $\begin{array}{l}\text { Social aspects have to be taken into } \\
\text { consideration, even at the expense of } \\
\text { efficiency. }\end{array}$ & 3,31 & 3,26 & 3,29 & 3,27 \\
\hline $\begin{array}{l}\text { If someone's performance isn't good enough, } \\
\text { he/she has to be fired. }\end{array}$ & $2,70^{*}$ & $2,48^{*}$ & $3,04^{* *}$ & $2,12^{* *}$ \\
\hline $\begin{array}{l}\text { The owner's interests are always most } \\
\text { important in dealing with conflicts regarding } \\
\text { the overall goals of the company. }\end{array}$ & $2,73^{*}$ & $2,55^{*}$ & $3,00^{* *}$ & $2,77^{* *}$ \\
\hline $\begin{array}{l}\text { If there are conflicts of interest within the } \\
\text { firm, the first aim should be to find a } \\
\text { compromise. }\end{array}$ & 1,94 & 2,06 & 1,95 & 2,01 \\
\hline $\begin{array}{l}\text { Tom p } \\
\text { (1) }\end{array}$ & & & & \\
\hline
\end{tabular}

(1) $* \mathrm{p}<.05, * * p<.01$. (2) Range: $1=$ total agreement, $5=$ total disagreement. (3) Number of cases: West German sample $\mathrm{n}=465$, East German Sample $\mathrm{n}=245$, "social market economists" $\mathrm{n}=387$, “competitive capitalists" $\mathrm{n}=324$.

(2) Although competition is highly rated as a general rule, the respondents assess the possibilities for acting as manager or entrepreneur differently. West Germans see more options to act, although the principles of capitalistic competition are valid. East German respondents are more orientated toward owners' interests, profits, and performance of employees. They seem to be more neo-liberal (see items 7, 9, and 10, Table 3). 
(3) The assessment of the consequences of business competition is also different. East German respondents believe to some extent that greater contrasts between competitiveness and social coherence as well as between free enterprise and social justice exist (see items 3 and 6, Table 3). In the view of East German respondents, the capitalist economy seems to be more problematic, but they only perceive limited options for action in alternative ways, because of assumed restrictions of economic competition. The higher frequencies of neo-liberal opinions among East Germans can be described as the "orthodoxy of proselytes" (Martens 2007b).

By means of cluster analyses, two different patterns of attitudes emerge: the "social market economists" and the "competitive capitalists" (Table 3). "Social market economists" recognise more options to alter the "rules" of competition, whereas members of the second cluster often underline the importance of owners' interests. They see more negative consequences of entrepreneurial endeavours, and they are against the participation of employees (codetermination by works councils [Betriebsräte], item 5, Table 3). The proportion of "competitive capitalists" in the sample of East Germans is nearly two thirds, whereas the corresponding percentage of the West German interviewees is $37 \%$. Tests with the survey data of 2005 reproduce this distribution of the clusters with respect to east and west.

The distributions of socio-political orientations must be explained differently, with reference to the East and the West German sample (Martens 2007b:126$128)^{14}$ : In the West German case, the situation of the company (negative operating results) and the absence of a works council have a positive impact on the probability of being a "competitive capitalist" (Table 4). In the East German sample the dominant pattern of attitudes depends on personal characteristics of the executives and entrepreneurs. If their income is relatively low, the proportion of "competitive capitalists" is higher. In other words, the conviction that "owners' interests are always most important" or that "the goal of an enterprise must always be to make the highest possible profit", opinions frequently endorsed by East Germans, seem to be rooted in the feeling that their own part of wealth is too small. "Competitive capitalists" are not an exclusive phenomenon of East German managerial elites. However, the statistical analyses demonstrate that in the East German case it is more correlated with the persons than with the firms. This result confirms findings of other research on East German managers. For instance, Breu (2000:157) writes about cognitive

14 The statement above referred to logistic regressions where the probability of being a "competitive capitalist" is estimated in dependence of some variables (regional background of the respondents, qualifications, age, voluntary work undertaken by respondents, company size, economic and financial situation of the firm, ownership of shares, income of the respondent, and existence of works councils [Betriebsrat]). 
differences in German management after unification. In the case of East German managers, she points to the "discrepancy between the [...] successful completion of their professional development of the market economic model and the continuity of empirically observed cultural differences to West German managers."

Table 4. Percentages of "competitive capitalists" according to three descriptive variables, an income of less equal 75,000 € denotes the median for the East Germans, survey 2002.

\begin{tabular}{|l|c|c|c|c|}
\hline Categories & \multicolumn{2}{|c|}{ West German sample } & \multicolumn{2}{c|}{ East German sample } \\
\hline & $\%$ & $\mathrm{n}$ & $\%$ & $\mathrm{n}$ \\
\hline Income less than or equal to 75,000€ & 45.2 & 62 & $68.1^{*}$ & 113 \\
\hline Income more than 75,000 $€$ & 34.8 & 348 & $54.7^{*}$ & 106 \\
\hline Negative operating result & $48.4^{*}$ & 64 & 66.7 & 24 \\
\hline Positive operating result & $34.1^{*}$ & 346 & 61.0 & 195 \\
\hline No works council & $46.1^{*}$ & 154 & 66.1 & 127 \\
\hline Existence of a works council & $32.8^{* *}$ & 311 & 55.9 & 118 \\
\hline
\end{tabular}

Notes: ${ }^{*} \mathrm{p}<.05, * * \mathrm{p}<.01$

\section{Future developments}

Investigations reveal that the past of the GDR economy still has a large influence on current development in the east. The reproduction of economic elites reinforced the traditional technical orientation of the GDR management. For a rather large proportion of managers, this led to a completion of their careers within one firm. Owing to the age structure of the East German entrepreneurs and executives, a remarkable generation change is probable in the future. This will presumably be connected with the transfer of companies within families and processes of social closure.

East German management exhibits more neo-liberal attitudes, but one cannot currently observe concrete realisation of such opinions to a significant extent. Two elements explain why the "orthodoxy of proselytes" is not yet frequently connected with corresponding neo-liberal management strategies at the shop level:

(1) Eastern firms possess limited financial resources. Profits are necessary to extend the companies' capital (equity capital), and can only be used restrictively by East German entrepreneurs for their own purposes, because the existence of the company would otherwise be rapidly affected. Consequently, the incomes of East German entrepreneurs and managing directors are significantly lower than those of their West German counterparts. 
(2) Often the mutual history of the transformation period is a resource for social relationships between management and workforce in East German companies. Accordingly, this historic base of social relations also restricts the realisation of neo-liberal attitudes. The difficult histories of privatisation were always present in our interviews with East German executives and entrepreneurs. Our respondents frequently told of their "gratitude" to the workforce that staff and management stood together during the troublesome transformation period. They conveyed their sense of responsibility for places of work and stressed their importance as local employers. One entrepreneur, who was interviewed by us, stated: "[...] unemployment is certainly extremely high in this area. And we are, with 150 employees, one of the most powerful enterprises in the region [...] in no case do we intend to shut the books and go elsewhere. 30 kilometres across the border [in the Czech Republic] we do not want this. We have very skilled workers" (interview 42).

The underlying social arrangement between staff and management restricting neo-liberal actions can be summarised by the slogan "working places against low wages and limited participation". In 2005 the gap between the average earnings of employees in East and West German industry was approximately 29 \% (Statistisches Bundesamt 2006:529). Behr and Schmidt (2005:106) cite an East German entrepreneur who stressed: "We as an eastern enterprise will always be forced to offer more cheaply, in order to get western orders. Without low wages, we could shut up shop." In another interview, the managing directors of a company located far in the east, at the Polish border, praised the "joy of deprivation" ("Entbehrungsfreude" $"$ ) as a special characteristic of his staff. But there are some indications that the implicit social arrangement between management and workforce, the "Nachwendepakt", is showing signs of fragility at least in some companies where the entrepreneurs are trying to obtain competitive advantages exclusively by low wages. Surveys among staffs of East German firms reveal processes of segregation within the workforces and growing levels of dissatisfaction with working conditions (Behr et al. 2008).

This erosion of traditional social arrangements denotes a first reason why the relations between workforce and management will probably change in the future. A second cause refers to processes within economic elites itself: the future change at the first hierarchical level of companies controlled by East Germans will also affect social relations, since each new generation ${ }^{16}$ of entrepreneurs will be forced to define its own relationship with staff.

15 Michael Behr, personal communication.

${ }^{16}$ In accordance with the study of Kotthoff and Reindl (1990), the social relationships between management and workforce in SME depend on the generation of entrepreneurs. Inheritors usually establish more formal or more instrumental social orders than the founders of enterprises. 


\section{References}

Abbott, A./Tsay, A. (2000): Sequence Analysis and Optimal Matching Methods in Sociology, in: Sociological Methods \& Research, 29, 3-33.

Bauer, M./Bertin-Mourot, B., (1999): National models for making and legitimating elites, in: European Societies, 1, 9-31.

Behr, M./Engel, T./Hinz, A. (2008): Wachsende Ungleichheit und blockierte Modernisierung der betrieblichen Sozialbeziehungen. Erosion des Nachwendepakts im verarbeitenden Gewerbe Ostdeutschlands, in: Benthin, R./ Brinkmann, U. (eds.): Unternehmenskultur und Mitbestimmung, Frankfurt/M.: Campus, 259-283.

Behr, M./Schmidt, R. (eds.) (2005): Aufbau Ost - Betriebliche und überbetriebliche Erfolgsfaktoren im verarbeitenden Gewerbe Ostdeutschlands, in: Jenaer Beiträge zur Soziologie, 16.

Best, H. (2007): Cadres into Managers: Strutural Change of East German Economic Elites before and after Reunification, in: Lane, D./Lengyel, G./Tholen, J. (eds.): Restructuring of the Economic Elites after State Socialism, Stuttgart: ibidem-Verlag, $27-44$.

Best, H./Remy, D. (eds.) (2006): Die geplante Gesellschaft. Analysen personenbezogener Massendatenspeicher der DDR, in: SFB 580 Mitteilungen, 18.

Bilton, T. (1996): Introductory Sociology, London: Macmillan $3^{\text {rd }}$ ed.

Breu, K. (2000): East German Managers in Transition. A Study into Individual Change in Transformative Contexts, München: Hampp.

Colli, A. (2003): The History of Family Business, 1850-2000, Cambridge: University Press.

Eberwein, W./Tholen, J. (1990): Managermentalität. Industrielle Unternehmensleitung als Beruf und Politik, Frankfurt a.M.: FAZ.

Faust, M./Jauch, P./Notz, P. (2000): Befreit und entwurzelt: Führungskräfte auf dem Weg zum ,internen Unternehmer“", München: Hampp.

Gergs, H.J./Hausmann, C./Pohlmann, M. (1997): Political and economic elites in the transformation process in eastern Germany, in: Best, H./Becker, U. (eds.): Elites in Transition, Opladen: Leske + Budrich, 203-248.

Günther, T./Gonschorek, T. (2006): Wert(e)orientierte Unternehmensführung im Mittelstand - Erste Ergebnisse einer empirischen Untersuchung, in: Dresdner Beiträge zur Betriebswirtschaftslehre, 114, 06.

Hatschikjan, M.A. (1998): Zeitenwende und Elitenwandel in Osteuropa, in: Hatschikjan, M.A./Altmann, F.L. (eds.): Eliten im Wandel, Paderborn, Schöningh, 251-269.

Hartmann, M. (1996): Top-Manager. Die Rekrutierung einer Elite, Frankfurt a M.: Campus.

Hartmann, M. (2002): Der Mythos von den Leistungseliten. Spitzenkarrieren und soziale Herkunft in Wirtschaft, Politik, Justiz und Wissenschaft, Frankfurt a.M.: Campus.

Institut für Mittelstandsforschung (2007): Eckdaten der Mittelstandsstatistik, http://www.ifm.uni-mannheim.de/unter/fsb/eckdaten/index.htm

Kollmorgen, R. (2005): Ostdeutschland. Beobachtungen einer Übergangs - und Teilgesellschaft, Wiesbaden: VS Verlag. 
Kotthoff, H. (1993): „Unternehmer sein, das lernt man nicht auf der Schule “Ökonomie, Organisation und Führung in mittelständischen Unternehmen, in: Ganter, H.D./Schienstock, G. (eds.): Management aus soziologischer Sicht. Unternehmensführung, Industrie- und Organisationssoziologie, München: Gabler, 234-262.

Kotthoff, H./Matthäi, I. (1999): Vom Kombinat zum Kleinbetrieb. Die Entstehung einer mittelständischen Industrie. Ein deutsch-tschechischer Vergleich, Berlin: Edition Sigma.

Kotthoff, H./Reindl, J. (1990): Die soziale Welt kleiner Betriebe, Göttingen: Verlag Otto Schwarz.

Kulke, D. (2005): Politisches Kapital, soziales Kapital und Humankapital in Ostdeutschland: Die Bedeutung individueller Ressourcen und struktureller Einflussfaktoren für den Wandel des ostdeutschen Managements in der Transformation, München: Hampp.

Lane, C. (1995): Industry and Society in Europe. Stability and Change in Britain, Germany and France, Aldershot: Edward Elgar.

Long, J.S. (1997): Regression Models for Categorical and Limited Dependent Variables, Thousand Oaks: Sage.

Martens, B. (2005): Der lange Schatten der Wende. Karrieren ostdeutscher Wirtschaftseliten, in: Historical Social Research, 30, Sonderheft: Unternehmer und Manager im Sozialismus, 206-230.

Martens, B. (2007a): Der Generationswechsel ökonomischer Funktionseliten in Ostdeutschland: Befunde und Szenarien, Proceedings, 33. Kongress der Deutschen Gesellschaft für Soziologie (in press).

Martens, B. (2007b): Orthodoxie der Proselyten - Einstellungsmuster ökonomischer Funktionseliten im Ost/West-Vergleich, in: Zeitschrift für Soziologie, 36, 118-130.

Martens, B./Michailow, M. (2003): Konvergenzen und Divergenzen zwischen dem ost- und westdeutschen Management - Ergebnisse einer Befragung von Leitern mittelständischer Industrieunternehmen in Ost- und Westdeutschland, in: SFB 580 Mitteilungen, 10, 13-55.

Martens, B./Michailow, M. (2006): Wandel und Kontinuität mittelständischer Unternehmen Eine Untersuchung $\mathrm{zu}$ Differenzen $\mathrm{zu}$ und Gemeinsamkeiten von Unternehmensleitern, in: Zeitschrift für KMU und Entrepreneurship, 54, 221-242.

Martens, B./Michailow, M./Schmidt, R. (eds.) (2003): Managementkulturen im Umbruch, in: SFB 580 Mitteilungen, 10.

Matthäi, I. (1996): Die neuen Unternehmer in Ostdeutschland - Träger eines neuen Mittelstandes?, in: Pohlmann, M./Schmidt, R. (eds.): Management in der ostdeutschen Industrie, Opladen: Leske + Budrich, 137-173.

Pohlmann, M./Gergs, H.J. (1997): Manager in Ostdeutschland - Reproduktion oder Zirkulation einer Elite? in: Kölner Zeitschrift für Soziologie und Sozialpsychologie, 49, 540-562.

Salheiser, A. (2006): Professionalisierung und Angepasstheit. Eine empirische Untersuchung zum Leitungspersonal der DDR-Industrie vor dem Hintergrund differenzierungstheoretischer Fragestellungen, in: SFB 580 Mitteilungen, 18, 77-98. 
Schreiber, E./Meyer, M./Steger, T./Lang, R. (2002): Eliten in „Wechseljahren“. Verband- und Kombinatsführungskräfte im ostdeutschen Transformationsprozess, München: Hampp.

Statistisches Bundesamt (2006): Statistisches Jahrbuch für die Bundesrepublik Deutschland, Wiesbaden: Statistisches Bundesamt.

Windolf, P. (2001): Die wirtschaftliche Transformation. Politische und ökonomische Systemrationalitäten, in: Schluchter, W./Quint, P.E. (eds.): Der Vereinigungsschock. Vergleichende Betrachtungen zehn Jahre danach, Weilerswist: Velbrück Wissenschaft, 392-413.

Windolf, P./Brinkmann, U./Kulke, D. (1999): Warum blüht der Osten nicht? Berlin: Edition Sigma.

Yamaguchi, K. (1991): Event History Analysis, Newbury Park: Sage. 